\title{
Several Comments on Creation and Use of PSE Indicator within Measuring of Financial Transfers to Agricultural Producers
}

\author{
I. Boháčková
}

Department of Economics, Faculty of Economics and Management, Czech University of Life Sciences Prague, Czech Republic

\begin{abstract}
Anotace
Článek je věnován problematice indikátoru PSE. Cílem je vymezit pozici EU v rámci vybraných zemí OECD (zemí srovnatelné ekonomické úrovně). V této souvislosti je hodnocena nejen vývojová tendence tohoto indikátoru, ale především je věnována pozornost struktuře PSE. Dále článek analyzuje problematiku PSE ve vazbě na př́ijmy zemědělských producentů a zisk zemědělských hospodářství, protože souvislost mezi těmito kategoriemi je pokládána za významnou. Metodika odpovídá stanoveným cílům (horizontální a vertikální analýza, komparace). Závěry jsou prezentovány se smyslu: hodnocení vývojových trendů PSE, struktury PSE, vhodnosti metodiky stanovení indikátorů, analýzy vztahu PSE, př́immo̊ a zisku.
\end{abstract}

\section{Klíčová slova}

Zemědělství, finanční transfery, odhad produkčních podpor, příjmy a zisk zemědělských hospodářství, Evropská unie

\begin{abstract}
The paper deals with problems of a PSE indicator. The aim is to delimit the EU position in the framework of selected OECD countries (countries of a comparable economic level). In this connection not only development tendency of this indicator is evaluated, but above all the attention is paid to the PSE structure. Further, the paper analyzes problems of the PSE in relation to incomes of agricultural producers and a profit of agricultural farms because the connection between these categories is considered significant. The methodology corresponds with set aims (a horizontal and vertical analysis, a comparison). Conclusions are presented in the sense: evaluation of development trends of the PSE, the PSE structure, suitability of the methodology of determination of indicators, analyses of the relation of the PSE, incomes and a profit.
\end{abstract}

\section{Key words}

Agriculture, financial transfers, estimation of production supports, incomes and profit of agricultural farms, European Union.

\section{Introduction}

An extent of supports flowing in agriculture has been already a subject of discussion hold at professional theoretical as well as practical level for a long time. At the same time, the amount of farmers' supports is still more often criticized even by the laic public. In evaluation of agrarian support it is always necessary to starts from the fact that their level is the result of political (resp. agrarian-political) decisions and tools. The decisions are made at the levels of national governments, eventually of institutions of integrated units, as in case of the European Union (further only the EU), and change in dependence on aims of agrarian policy and on domestic and foreign economic and political environment.

The adopted measures in area of supports can be and they are of various character. For example in Europe measures are known in the historical context supporting overcoming of lack of foods (after the World War II) and vice versa solving food surpluses (e.g. the CAP reform from 1992); at this time measures for support of food safety, measures leading to maintenance or improvement of quality of the environment ("agri-environmental" measures), measures for maintenance of settlement in the country and supporting development of so called rural regions, measures supporting development 
of entrepreneurial farmer activities, and many others including support of agrarian markets. Various supporting tools are used by both the advanced world countries (more significant farmer support), and countries less developed or developing (less significant support). In the advanced world the provision of supports in agriculture already from the beginning of their existence has one common and long-term aim - maintenance and growth of agricultural incomes. According to Anderson and Martin (2006) this aim is in fact the most important aim. It is possible to absolutely agree with this statement. Also other authors put brains to relation of financial transfers and farmer incomes in the area of support of commodity market, support and protection of agrarian markets, and differences among states, e.g. Tagermann (Tagermann, Koester 1977, Tangermann 2004), Bielik (Bielik, Juríček, Kunová 2007), Färber, (Färber, Seidel 2002) an others.

Measures which in practice have a form of agrarianpolitical tools are oriented in areas which influence incomes of agricultural producers in a substantial way. To illustrate this point we can name e.g.:

- institutional interventions in market environment of agrarian products (by means of setpricesystem, e.g. by existence of intervention prices),

- subsidisation of inputs in agriculture,

- protective import barriers, which enable domestic producers to sell for higher prices than importers would offer (these are disadvantaged by treshold prices including customs duty and other costs). Domestic producers are in this way preferred to the interest of domestic consumers, i. e. purchase for as lowest prices as possible.

- $\quad$ on the contrary a support of domestic export (export subsidies),

- a support of use of services for agriculture,

- tax relieves as a part of agricultural supports (This advantage which moreover makes monitoring of supports more difficult, is pointed out by Wilhelm (2009),

- $\quad$ and others.

Because all mechanisms and tools of granting of agricultural supports differ in particular states, objectively there is need of a methodological approach which would enable to monitor the agricultural support rate in comparable way in various states and systems. In this area, OECD is active; so called indicators of agricultural support started to be monitored here in selected states from 1980's. These indicators have passed several changes during its existence; nevertheless, their sense is still maintained.

1. to measure what economic effect of support they bring to farmers,

2. what is the rate of re-distribution of public means in favour of farmers

3. to serve as a basis for monitoring of impacts of agrarian policy

4. to be information which could enable an objective dialogue between farmers and national governments as well as among governmental organizations (resp. institutions of integrated units as the EU is) and supranational institutions (WTO, FAO, MMF, World bank)

At present states in the area of supports are compared by the help of four basic indicators and others which are derived from these basic ones. The basic indicators are:

- Producer Support Estimate (PSE) which monitors support in relation to farmers' income,

- Consumer Support Estimate (CSE) which takes into account agrarian political transfers for consumers of agricultural commodities,

- General Services Support Estimate (GSSE) expressing support to services for agriculture (including research, education etc.),

- Total Support Estimate (TSE) expressing a rate of re-distribution of public means in favour of agriculture.

WTO brings other question. This approach divides supports flowing in agriculture according to their character into groups (box). So it distinguishes "Amber box" (support relating to the production), "Blue box" (supports connected with limitation of production), "Development box" (developing supports), "Green box" (supports deforming market in a minimal rate). „Aggregate Measure of Support - AMS approximates the most to the PSE indicators in this category. AMS includes supports tied to commodity (e.g. a support of market prices) in relation to the value of production. Effland (2001) dealt with problems of comparison of AOCD and WTO system. She states that in case of PSE and AMS the starting points and aim are moreover the same. However, methodology 
and support structure are different. The PSE includes more kinds of supports than AMS and refers the supports to farmers' incomes. AMS works with a narrower extent of supports and gives these in connection with the production value (OECD left this approach). On dates 1995 -2007 of USA agriculture it documents significant quantitative differences between values of both the monitored indicators.

\section{Materials and methods}

Aim of the paper is to determine EU position within selected OECD countries (countries of a comparable economic level) by the help of indicator PSE. The EU will be in this connection compared not only by a development tendency of this indicator, but above all attention will be paid the PSE structure. The PES structure has a high predicative ability about agri-political orientation of supports flowing in agriculture and not big attention has been paid to it yet. Further the paper deals with problems of PSE in relation to incomes of agricultural producers.

The methodological side results from chosen aims. A starting point for analysis of PSE construction will be the existing methodology of OECD. Quantitative data will be analyzed by the help of horizontal and vertical analysis with subsequent comparison.

At present the PSE is monitored at two levels, at the level of agricultural commodities, and at the level of agricultural farms. The paper orientates on problems of monitoring of PSE at the farm level in national or supranational dimension (EU, OECD). The level of supports of producers is in this case monitored partially by the basic indicator PSE and partially by indicators derived from it: Percentage Producer Support Estimate (\% PSE), Producer Nominal Assistance Coefficient (NAC) and Producer Nominal Protection Coefficient (NPC). NAC and NPC are considered moreover equivalent.

PSE is defined as: The annual monetary value of gross transfers from consumers and taxpayers to agricultural producers, measured at the farm gate level, arising from policy measures that support agriculture, regardless of their nature, objectives or impact on farm production or income. (OECD, 2013)

From the quantification point of view it is based on value of state budget contribution (in the EU also on contributions from the EU budget), i.e. on a value incurred by re-distribution of public means and other transfers advantaging agricultural producers.

$P S E c=M P S c+B O T c$,

where

$P S E c=$ PSE of concrete country

$M P S c=$ market price support

$B O T c=$ other transfers

$c=$ marks a concrete country

Indicator \%PSE is defined as a share of gross farm receipts (including support).

$\% P S E=P S E c .100$

GFRc

where

$P S E c=$ PSE of concrete country

$G F R c=$ Gross Farm Receipts

$G F R c=V P c+B O T c$,

where

$V P c=$ Value of Production

$B O T c=$ Budgetary and Other Transfers

$N A C c=G F R c$,

$V P c-M P S C$

where $M P S c=$ budgetary transfers

Producer Nominal Protection Coefficient (NPC): The ratio between the Price received by producer (Including Payments per tonne of current output) and the border Price (measured at the farm gate)

$N P C c=V P c+P O c$,
$V P c-T P C c-T P T c$

where

$T P c=$ Transfers to Producers from consumers

$T P T c=$ Transfers to Producers from Taxpayers

\section{Results an discussion}

\section{Analysis of PSE development and structure}

\section{PSE in historical context}

Indicators of agricultural support have passed several changes in its history. The OECD Ministerial Council Decision 1982 on deepening of trade liberalization and reduction of protectionism brought a pressure on concerned countries in order 
to reduce mainly such a rate of farmers support which leads to deformation of agrarian markets. By reason of comparison and check of support rate the already above mentioned indicators were introduced.

Considering the PSE - its second revision (see the table 1) is actual at present. Adjustments referred mainly to the indicator structure, it means, types of transfers were implemented or removed according to character of agri-political measures. However, changes happened also in the indicator construction and terminology.

The first form of PSE indicator (1987-1999) included substantially less transfers than today. In the PSE construction supports of market prices, direct payments, supports of reduction of inputs and services were taken into account. This structure corresponds with effort to catch rate of protectionism in particular countries (or supranational units), above all in the area of agrarian markets. Among others, Corden (1973) focused on deformation of agrarian markets in the 1960's invoked thanks to protective measures in the area of foreign trade with agricultural commodities (import limitation, customs tariffs, export subventions). He warned of the fact that it is necessary to look at the protectionism as at a financial transfer. His approach was applied later in empirical measurement of agricultural support by Joslin $(1975,1998)$. The indicator was in this period called Producer Subsidy Equivalent (PSE) and was defined as "the payments that would be required to compensate farmers for the loss of income resulting from the removal of a given policy measure“" (OECD 1987).
A sense of the given indicator clearly results from this definition - i.e. to monitor supports to agricultural enterprises as a compensation of income decrease which follows from agripolitical interventions. The first EPS revision happens in 1998/1999. From the fundamental changes it is possible to mention the following:

- the indicator got a name Producer Support Estimate. This name reflected better the reality, it is not possible always and everywhere to catch up all support in full extent, however, it is dealt with their "estimation",

- from the structure general services were excluded and an individual GSSE indicator arose,

- the number of included supports increased by other areas with the aim to separate supports tied to production from the others.

- monitoring of supports tied to area/animals in actual and historical dimension started,

- the volume of supports no longer referred to the production value, but to so called gross farms receipts. Gross receipts do not represent real incomes of farmers, however, they are methodically determined as a sum of PSE from which supports of market prices and production values are excluded.

A subject of discussion a question became, whether to include also relieves in the support (tax, social, etc.), and if so, in what way. Solution of this problem was complicated by various systems of monitoring of relieves used in particular countries.

A result of the second revision (2007) is the current

\begin{tabular}{|l|l|c|l|c|l|}
\hline \multicolumn{2}{|c|}{1986} & \multicolumn{2}{c|}{ Revision 1997-9 } & \multicolumn{2}{c|}{ Revision 2007 } \\
\hline A & Market price support & A & Market price support & A & $\begin{array}{l}\text { Support based on commodity output (market } \\
\text { price and payments based on output) }\end{array}$ \\
\hline B & Direct payments & B & Payments based on output & B & Payments based on input use \\
\hline C & Reduction in input costs & C & $\begin{array}{l}\text { Payments based on area } \\
\text { planted/animals number }\end{array}$ & C & $\begin{array}{l}\text { Payments based on current A/An/R/I } \\
\text { production required }\end{array}$ \\
\hline D & General services & D & $\begin{array}{l}\text { Payments based on historical } \\
\text { entitlements }\end{array}$ & D & $\begin{array}{l}\text { Payments based on non current A/An/R/I } \\
\text { production required }\end{array}$ \\
\hline E & Other & E & $\begin{array}{l}\text { Payments based on input use } \\
\text { E }\end{array}$ & $\begin{array}{l}\text { Payments based on non current A/An/R/I } \\
\text { production non required }\end{array}$ \\
\hline & & F & $\begin{array}{l}\text { Payments based on input } \\
\text { constraints }\end{array}$ & F & \begin{tabular}{l} 
Payments based on non-commodity criteria \\
\hline
\end{tabular} \\
\hline
\end{tabular}

Note: A-Area, An-Animals Number, R-Receipts, I-Income Source: The PSE Manual, OECD 2008

Table 1: PSE structure in historical context. 
form of PSE. Six principles is taken in to account in the indicator construction which can be in introduce in a simplified form:

1. principle: includes criterion of clearly determined receiver. It is an agriculture enterprise (as a producer) whether its owner is an individual farmer or a group of owners.

2. principle: financial transfers accounting traceable,

3. principle: transfers resulting from general political measures, although they can influence agriculture, are not monitored,

4. principle: transfers are defined as "gross" (gross incomes). Producers' costs (including taxes) are not included because they would change fundamentally the transfers to "net" incomes.

5. principle: supports refer to primary producers. Supports from tax payers are delimited by state budgets; in supports from consumers the consumer is understood as a buyer of agricultural commodities at the first level (processor, trade),

6. principle: political measure are divided according to implementation criterion for supports provided per production base (a unit of output, area, farm animal), support of production and sale, and others.

At present the structure of used indicator PSE is created by several groups: payments supporting commodity outputs (support of market prices, support of sale), payments supporting input use (variable/fixed) and support of services, payments provided for state of areas, animals and revenues with requirement of production (on current) and without the requirement of production (on non current) for the actual or historical state, and further various payments for no-commodity outputs and other supports. All above mentioned groups have either a direct or indirect relation to producers' incomes, however, an influence on incomes are shown by all.

\section{PSE development in selected countries}

If we would like to obtain real information about the PSE development, it is necessary to start from the fact that two fundamental changes happened in this indicator's construction: in 1997 and 2007. There were not only changes in ranking the particular kinds of transfers, but also the comparative base the production value was replaced by producers' incomes. Therefore, it is not possible to monitor the period from origin of PSE (1986) to the present as a continuous time series. Therefore, 27 years of PSE existence was divided into 3 sections-periods which correspond with time validity the appropriate methodology (the $1^{\text {st }}$ period $1986-1996$, the $2^{\text {nd }}$ period: 1997-2006, the $3^{\text {rd }}$ period: 2007-present). At the same time it is not possible to compare (from a view-point of maintenance of principle of comparability) absolute values of PSE. For the comparison the variant of \%PSE indicator was used.

In comparison of data in particular periods (see the table 2) in which the support of agricultural producers was measured by the help of \%PSE it is possible to state that in all periods in the monitored countries there is an obvious decreasing tendency of representation of financial transfers in production value and incomes. We can obtain the orientation comparison from basic index (see the table 3). From its value it is obvious that the approach to reduction of supports differs from particular countries. More significant decrease of financial transfers in agriculture happens paradoxically in countries where their value is traditionally low (the USA, Australia with the exception of the $2^{\text {nd }}$ period). On the contrary, where the PSE value is high a more significant decrease would be presumed, only very slow decrease in the PSE happens and in the 3rd period the PSE even grows (Norway, Switzerland, Japan). The reason for these facts can be among others also an approach of national governments to agricultural producers and agrarian lobbyism. Objectively the \%PSE is influenced by development of volume of financial transfers and development of production value, resp. of gross incomes creating the comparative base. A standard situation leading to decrease in the \%PSE is, if the base grows (production value, gross incomes) and also financial transfers grow, but slower (OECD, EU). In the monitored periods also other variants appear leading to development of \%PSE. For example the \%PSE decreased when the base grew and the value of financial transfers decreased (Australia, the USA), or the value of base decreased, but the value of financial transfers decreased faster (Japan). The \%PSE increased when financial transfers grew faster than the base (Norway), or when the dimension of base decreased, but financial transfers grew (Switzerland).

From the mention it is obvious how different the approaches of agrarian policies to this sensitive 


\begin{tabular}{|c|c|c|c|c|c|c|c|c|c|c|c|c|}
\hline \multicolumn{13}{|c|}{ 1. period (1986-97) - \% Producer Subsidy Equivalent } \\
\hline & 1986 & 1987 & 1988 & 1989 & 1990 & 1991 & 1992 & 1993 & 1994 & 1995 & 1996 & 1997 \\
\hline OECD & 37.6 & 38.3 & 35.2 & 31.6 & 31.8 & 34.9 & 33.2 & 34.2 & 33.8 & 31.1 & 29.6 & 28.2 \\
\hline EU & 38.6 & 41.6 & 37.4 & 29.3 & 32.9 & 38.3 & 34.5 & 36.7 & 35.6 & 34.8 & 33.8 & 32.2 \\
\hline Norway & 69.6 & 71.9 & 69.6 & 65.7 & 71.3 & 72.9 & 70.3 & 69.4 & 70 & 64.3 & 66.3 & 38.3 \\
\hline Switzerland & 74.5 & 76.8 & 77.2 & 65.1 & 71.1 & 72.5 & 63.9 & 70.2 & 71.9 & 64.2 & 68.6 & 69.1 \\
\hline USA & 24.1 & 23.1 & 18.4 & 21.3 & 16.7 & 17.1 & 16.9 & 17.9 & 14.1 & 10.1 & 13.3 & 13.7 \\
\hline Australia & 12.9 & 9.1 & 8.3 & 7.5 & 8 & 8.8 & 9.9 & 9.2 & 9 & 6.5 & 6.3 & 4.6 \\
\hline Japan & 65.1 & 64.6 & 62.2 & 56.8 & 51.6 & 51.7 & 56.9 & 57.5 & 62.7 & 62.2 & 58 & 54.3 \\
\hline \multicolumn{13}{|c|}{ 2. period (1998-2006) - \%Producer Support Estimate } \\
\hline & 1998 & 1999 & 2000 & 2001 & 2002 & 2003 & 2004 & 2005 & 2006 & & & \\
\hline OECD & 32.1 & 35.2 & 32.2 & 28.8 & 30.5 & 29.2 & 30.1 & 28.5 & 26.4 & & & \\
\hline EU & 35.2 & 38.2 & 32.7 & 30.2 & 33.8 & 33.7 & 32.6 & 30.4 & 29 & & & \\
\hline Norway & 70.8 & 71.2 & 66.5 & 65.3 & 73.7 & 71.1 & 66.3 & 65.8 & 64.1 & & & \\
\hline Switzerland & 71.6 & 75.3 & 69.8 & 67.3 & 70.6 & 69.1 & 69.2 & 66.1 & 65.3 & & & \\
\hline USA & 21.6 & 25.5 & 23.3 & 22.1 & 18.5 & 15.1 & 16.3 & 15.3 & 11.2 & & & \\
\hline Australia & 4.9 & 3.9 & 3.3 & 4.7 & 3.7 & 3.4 & 3.6 & 3.6 & 4.5 & & & \\
\hline Japan & 58.2 & 59.9 & 59.7 & 56.3 & 57.2 & 57.5 & 55.9 & 53.8 & 51.6 & & & \\
\hline \multicolumn{13}{|c|}{ 3. period (2007-2011) - \%Producer Support Estimate } \\
\hline & 2007 & 2008 & 2009 & 2010 & 2011 & 2012 & & & & & & \\
\hline OECD & 22 & 21 & 22.7 & 19.9 & 18.8 & 18.6 & & & & & & \\
\hline EU & 23.5 & 22 & 23.3 & 19.8 & 17.5 & 19 & & & & & & \\
\hline Norway & 55.6 & 59.4 & 61.2 & 60.1 & 57.7 & 63.1 & & & & & & \\
\hline Switzerland & 48.8 & 56 & 60.3 & 53.5 & 54.4 & 56.7 & & & & & & \\
\hline USA & 10 & 8.8 & 10.6 & 7.7 & 7.7 & 7.12 & & & & & & \\
\hline Australia & 5.1 & 4.4 & 3.1 & 2.7 & 3 & 2.3 & & & & & & \\
\hline Japan & 46.7 & 48.3 & 48.9 & 53.3 & 51.6 & 55.9 & & & & & & \\
\hline
\end{tabular}

Source: Monitoring and evaluation: Reference Tables. OECD.STATExtracts-Complete databases available via OECD's iLibrary

Table 2: Development of \%PSE in the period 1986-2011.

\begin{tabular}{|l|c|c|c|}
\hline & 1. period & 2. period & 3. period \\
\hline OECD & 0.75 & 0.82 & 0.85 \\
\hline EU & 0.83 & 0.82 & 0.81 \\
\hline Norway & 0.99 & 0.91 & 1.14 \\
\hline Switzerland & 0.93 & 0.91 & 1.16 \\
\hline USA & 0.57 & 0.52 & 0.71 \\
\hline Australia & 0.36 & 0.92 & 0.46 \\
\hline Japan & 0.83 & 0.89 & 1.2 \\
\hline
\end{tabular}

Source: author

Table 3: Development of \% PSE in all time periods, measured with basic index (base $=$ starting year of the time series).

area are and how deceptive is to make unambiguous conclusion in the sense that the general interest is decrease of financial transfers flowing to support agricultural producers. Concerning the EU as a whole, a continuous decrease in the \%PSE happens in all time periods, even if not so significant.

\section{PSE structure}

PSE structure changed in historical context (see the table 1).To the original supports included in PSE also other kinds of supports were added and on the contrary some general services were 
excluded from PSE and they are an individual indicator at present. Ranking of particular kinds of supports is the methodological matter, however, also agri-political. If supports really exists, it is possible to discuss justification of their existence, nevertheless it is not possible to infirm their role and to decide within PSE which supports should be ranked and what should not because all has an impact on producers' incomes.

Rather it is possible to thing about supports which are not included in the PSE and what incomes they also influence. It is dealt for example with inclusion of financial transfers flowing in agriculture from relieves on social security, relieves on fuels, transfers which are results of general political decisions concerning also agriculture etc. The problems of tax relieves for farmers were investigated by Wilhelm (2009), who monitors not only tax advantages (relieves) but also on the other hand he deals with the fact that some inputs in agriculture are tax-disadvantaged (e.g. taxes on pesticides, fertilizers). These transfers are applied in various countries in varying degrees; they are not included in the present methodology, and their quantification is difficult. Nevertheless, they exist and influence the producers' incomes. the PSE is really an estimation serving above all for comparison, not a real value. The table 4 stating the present PSE structure in selected countries including the EU as a whole offers interesting results.
The support tied to the commodity market (category A) represents at average of monitored OECD countries the most significant item $(47.6 \%)$. Within this average there are significant differences. Norway and Switzerland show traditionally high values, on the contrary a small market support is in the USA, and zero support in Australia. In the EU as a whole, the support of commodity market represents only a fifth of all supports in the framework of the PSE. A strong interest of the Common Agricultural Policy (CAP) shows itself in decrease of deformation of agrarian market. Within the support of commodity market generally support of market prices is supported; a support of sale is not significant.

Also supports tied to inputs (category B) show big differences in the monitored countries. While in the USA and Australia they represents $30-40 \%$ of all supports in PSE, in Norway and Switzerland they are minimal. Nor in the EU the value c. $14 \%$ represents a significant financial means. Interesting is not only the representation of supports to PSE inputs, but also their internal structure. In theUSAandAustraliatheemphasis is putonsupport of services for producers, in Norway and Switzerland supports of variable inputs prevail (In Australia they are zero). In the EU and Australia an emphasis is put also on support of fixed capital.

The categories C, D, E are represented by all forms of supports tied to the area, animals, receipts and incomes. Their sum creates an important part

\begin{tabular}{|c|c|c|c|c|c|c|c|c|c|c|c|c|}
\hline & \multicolumn{2}{|c|}{ OECD (\%) } & \multicolumn{2}{|c|}{$\mathrm{EU}(\%)$} & \multicolumn{2}{|c|}{ USA $(\%)$} & \multicolumn{2}{|c|}{ Australia (\%) } & \multicolumn{2}{|c|}{ Norway (\%) } & \multicolumn{2}{|c|}{ Switzerland (\%) } \\
\hline PSE & 100 & & 100 & & 100 & & 100 & & 100 & & 100 & \\
\hline A & 47.6 & 100 & 20.9 & 100 & 11.9 & 100 & $\mathbf{0}$ & 0 & 51.6 & 100 & 44.6 & 100 \\
\hline A 1 & & 94 & & 96 & & 85 & & 0 & & 86 & & 88 \\
\hline A 2 & & 6 & & 4 & & 15 & & 0 & & 14 & & 12 \\
\hline B & 12.4 & 100 & 13.9 & 100 & 32.5 & 100 & 38.3 & 100 & 5 & 100 & 1.6 & 100 \\
\hline B 1 & & 38 & & 37 & & 33 & & 0 & & 55 & & 88 \\
\hline B 2 & & 38 & & 52 & & 19 & & 55 & & 38 & & 11 \\
\hline B 3 & & 24 & & 11 & & 48 & & 45 & & 7 & & 1 \\
\hline $\mathrm{C}$ & 14.4 & & 17.3 & & 26.8 & & 23.6 & & 30.9 & & 23.5 & \\
\hline $\mathrm{D}$ & 23.1 & & 45.5 & & 19.6 & & 37 & & $\mathbf{0}$ & & 21.4 & \\
\hline $\mathrm{E}$ & 2 & & 2.1 & & 9 & & 1.1 & & 0.2 & & 3.5 & \\
\hline $\mathrm{F}+\mathrm{G}$ & 0.5 & & 0.3 & & 0.2 & & $\mathbf{0}$ & & 12.3 & & 5.4 & \\
\hline
\end{tabular}

A-support based on commodity output, A1-market price support, a2-payment based on output, B - Payment based on input use, B1- Payment based on variable input use, B2- Payment based on fixed capital formative, B3-Payment based on farm services, C-Payment based on current A/An/R/I Production required, D-Payment based on non-current A/AN/R/I production non required, E-Payment based on non commodity criteria, $\mathrm{F}+\mathrm{G}-$ miscellaneous payments

Source: author 
of the PSE moving in an interval of values from $48.8 \%$ (Switzerland) to $64.9 \%$ (EU).

\section{Relation of PSE, incomes and profit of agricultural producers}

It would be easy to adopt an idea that the financial transfers (PSE) increase agricultural incomes and profit of agricultural farms. On the EU example it is possible to demonstrate that this statement would be simplifying. The PSE contributes, as a subsidiary financial tool, to producers' incomes, it cannot be denied; however, it does not mean that it is decisive factor in their creation. Especially it is true in the profit. Financial transfers in favour of producers are a significant item (without their existence incomes and profit would reach lower values), but besides them they are also other factors which have a relevant influence both in the area of inputs and the outputs. In the graph 1, development of absolute PSE values, agricultural incomes (indicator A) and profit (indicator C) are monitored by the help of basic index in the EU in the period $1998-2013$. It is obvious that the monitored indicators do not always develop in the same way, and there are considerable differences in particular years. For example the PSE decreased, however, producers' incomes and profit increased (2000, 2001, 2006, 2007, 2010, 2011). But vice versa, the PSE grew, however, incomes and profit decrease (1999, 2002, 2004, $2008,2012)$. Only in 3 years $(2003,2005,2009)$ the development of all indicators agreed.

\section{Producer Nominal Assistance Coefficient, Producer Nominal Protection Coefficient}

NAC and NPC are indicators which in principle quantify differences between gross incomes, resp. the production value in price relations (including transfers) of the given country and gross incomes, resp. the production values, if they are expressed in world prices. They try to express a rate of protectionism for the given country, resp. given integration unit (the EU). From the graph 2 it is obvious that the development of indicators NAC and NPC is in fact identical in the EU. This fact leads sometimes to conclusions that VAC and NPC are equivalent in fact. Looking at the mentioned graphs it is clear that the development tendency is the same; however, values which characterize NAC and NPC are absolutely different. It is interesting that in the first period $(1986$ - 1997) the values

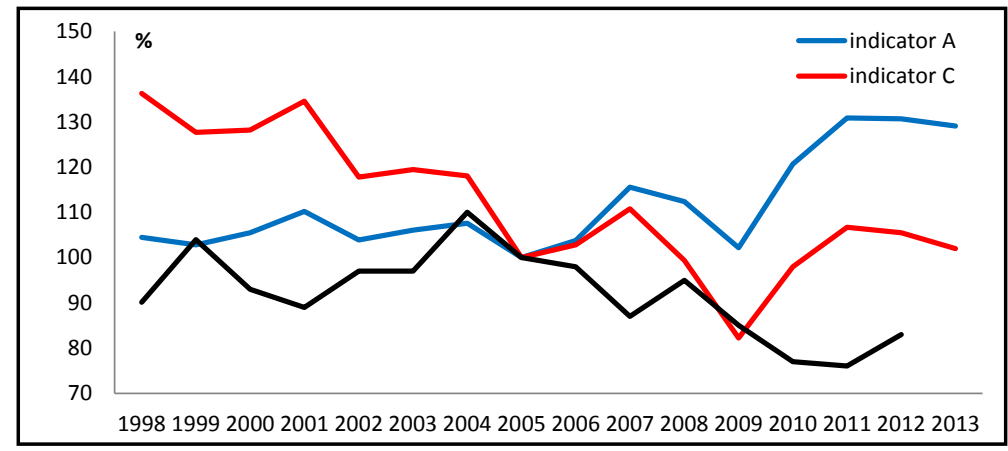

Source: own processing

Graph 1: Relation between PSE, EU agricultural incomes (A), gross incomes (OECD), and profit (C) in the EU, $1998-2012,(2005=100)$

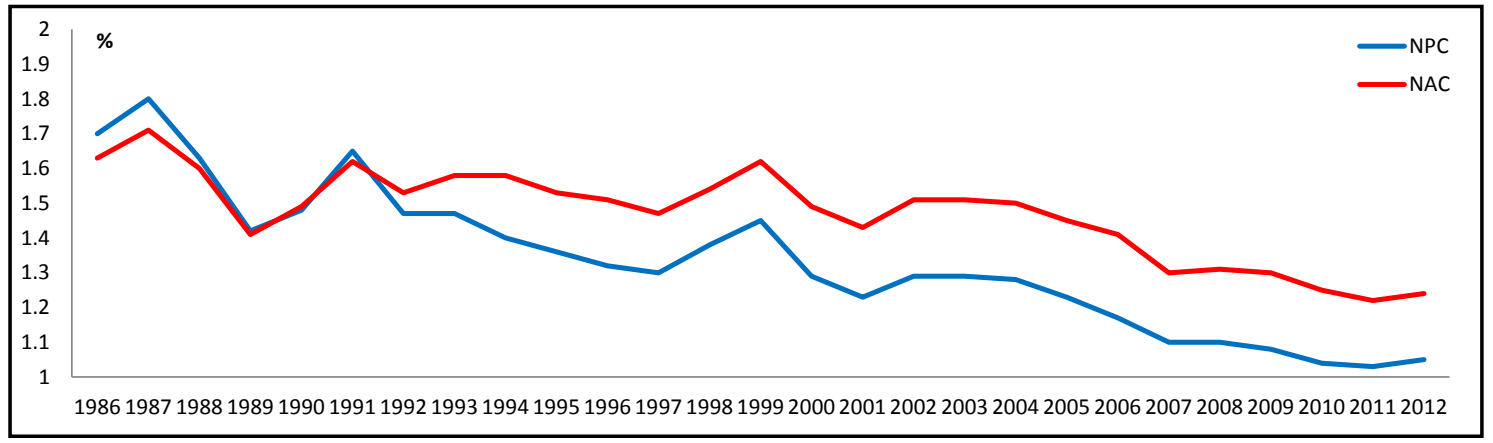

Source: own processing

Graphs 2: Development of NAC and NPC in development periods 1986-2012. 
NAC and NPC moves relatively close together; in other time periods the values move apart more significantly. Therefore, it is not possible to evaluate these indicators as identical quite unambiguously.

\section{Discussion}

Results of analyses of concrete data of the PSE (see the summary) are very significant for agripolitical measures. However, no less important is also what methodology led to the monitoring and calculations of the PSE. To this topic it is possible for all the questions discuss the following:

- above all it should be decided what all the PSE is about to express. At present, the PSE is understood as estimated financial transfer in favour to farmers from tax payers and consumers. As it is seen from the PSE genesis, kinds of financial transfers included in PSE changed with the effort to include as biggest number of transfers as possible, nevertheless it is obvious that all kinds of transfers cannot be caught up in accounting, so it is dealt only with transfers which can be caught up in accounting (the principle 2). As the first methodological step it is possible to consider a decision making whether:

a) the methodology will be led by an effort to catch as biggest number of supports as possible or

b) the methodology will refer only to significant kinds of supports.

- if the variant a) will be chosen, than it is necessary so that the most supports as possible were caught up in accounting in order that they could be qualified. Even in this case it will be always dealt with an estimation and not exact numbers. The more meaningful seem to be the variant b). For example at present when there is a world-wide pressure on reduction of supports deforming agrarian markets it would be suitable to categorize financial transfers in areas - agrarian market, production base, incomes and others. This categorization is easy regarding the internal PSE structure (see the table 4); however, the aggregated indicators do not enable this resolution. The commodity indicators are much more transparent. If particular categories of transfers show disproportions, than it would be very easy to react with agrifood tool.

- also it is possible to discuss the base with which the indicator PSE is compared. At present, this base is so called "gross incomes" (a value of production including support of market prices + the PSE cleaned from the support of market prices). It is obvious that not all financial transfers are tied to production; therefore it is possible to discuss why the construction of "gross incomes" is chosen just in this way. According to the $4^{\text {th }}$ principle, deductions of costs and taxes co-creating "profit" are not included. It is possible to agree with that, nevertheless, all incomes originating from agricultural activity should be taken into account. In this case the biggest progress is the EU methodology quantifying agricultural incomes by the help of the general agricultural account.

\section{Conclussion}

The results summary concerns concrete findings on base of the PSE quantification. The methodological side was discussed above (see the Discussion).

Countries with high rate of support of agricultural producers (measured by the PSE) do not show more significant activities for its reduction; vice versa it grows in recent years (Norway, Switzerland, Japan). Countries with a traditionally low PSE value are more willing to decrease of the indicator (the USA, Australia). These different approaches are a result of national agrarian policies, including influence of agricultural lobby.

In the framework of the PSE, particular categories of transfer have various representations. The commodity market (A) is supported the strongest in the framework of the monitored countries in Norway and Switzerland, however, also the average value of OECD (48 \%) document that it is in most countries. From the found out values it is possible to judge a significant fact that incountries where transfersinthe commoditymarkets are decreased, these "saved" means are poured into categories of supports tied to the area, animals, and also revenues and incomes $(\mathrm{C}, \mathrm{D}, \mathrm{E})$. It is interesting that countries which significantly support their farmers in the market areas have a minimal input support (Norway $5 \%$, Switzerland $1.6 \%$ ). The opposite are countries where market support is relatively low (the USA) or none (Australia). There these transfers represent $30-40 \% \mathrm{PSE}$. The average value of OECD (12\%) also indicates the fact that 
countries included in the monitoring mostly do not prefer the input support. It is worth noting also the fact that a desirable support of fixed capital inputs in agriculture is realized by Australia (55\%) and the EU (52\%). On the contrary variable inputs are supported in Norway (55\%) and Switzerland (88\%).

The EU development tendency of \%PSE corresponds with strategic aims of the CAP - to decrease a share of supports in the production value (gross incomes). The decrease of indicator is not strong, but it is continuous (see the table 3 ).
In the PSE structure in the EU as a unit it is obvious a tendency to decrease a share of support of agrarian market and to reduce thereby their deformations. According to the last published data the share of market support is $21 \%$ (96\% is created by market price support, $4 \%$ by sale support). Also input support is not a dominant item. On the contrary, transfers tied to production base (an area, a number of animals) as well as results (revenues, incomes) create $64 \%$ PSE in the EU. This is an illustrative case when there are shifts among categories within PSE.

Corresponding author:

Prof. Ing. Ivana Boháčková, CSc.

Department of Economy, Faculty of Economics and Management,

Czech University of Life Sciences Prague, Kamýcká 129, Praha 6-Suchdol, 16521, Czech Republic

E-mail: bohackiv@pef.czu.cz

\section{References}

[1] Banders, S. M., Harsche, J., Salhofer, K., Teuber, R. The interregional and intertemporal allocation of EU producer Support: Magnitude and determinants, Review of regional research, Springer Berlin. 2007, vol. 27, p. 171-193. ISBN 0173-7600.

[2] Anderson, K., Martin., W. Agriculture, Trade and the Doha Agenda in Agricultural Trade reform and the Doha Development Agenda, Washington and the World Bank, 2006. [Online] Available: ht t p: / / siteresources.worldbank.org/intranettrade/resources/internaltraining/287823-1116536061368. [Accessed: 28.11.2013].

[3] Bielik, P., Juríček, P., Kunová, D. The comparison of agricultural support policies in the OECD and the EU countries from the perspective of economic globalization process. Agricultural Economics - Czech, ÚZEI Prague. 2007, 53, p. 339-348, ISSN 0139-570X.

[4] Butault, J. Evolution of agricultural support in real terms in OECD countries and emerging economies, 1971. [Online] Available: http://www.oecd-library.prg/agriculture...food/oecd_foof_ agriculture_and_fisheries_working paper 37, 18156797 [Accessed: 20.2.2014].

[5] Corden, W. M. The Theory of Protection. Journal of Political Economy. The University of Chicago Press. 1973, vol. 81, No. 2, p. 504-506. ISSN: 0022-3808; E-ISSN: 1537-534X.

[6] Corden, W. M. Effective Protection Revisited”, in Corden, W.M. Protection, Growth and Trade: Essays in International Economics. Oxford, 1985. [Online] Available: http://fbe.unimelb.edu.au/_ data/assets.../Effective_protection_and1.pdf. [Accessed: 2.2.2014].

[7] Effland, A. Classifying and Measuring Agricultural Support- Identifying Differences Between the WTO and OECD Systems, Economic Informatic Bulletin, Economics Researck Service/ USDA, 2011, No.74 [Online] Available: http://www.ers.usda.gov/publications/eib74 [Accessed: 15.12.2013].

[8] Eurostat. [Online] Available: http://epp.eurostat.ec.europa.eu/portal [Accessed: 14.7.2014].

[9] Färber, G., Seidel, B. Subventionsabbau: Fürhrt eine andere Subventionspolitik endlich zum Erfolg? $1^{\text {nd }}$ edition, Waxmann, 2002. ISBN-13:9783830911302.

[10] Hansen, H., Harsche, J. Die Förderung landwirtschaftlicher Erzeugnisse durch die Europäische Agrarpolitik: Regionale Auswirkungen in Deutschland und Bestimmungsgrunde.Institut 
für Agrarpolitik, Giesen. 2005. [Online] Available: http://geb.uni-giessen.de/geb/volltext/2005 [Accessed: 3.11.2013].

[11] Hennig, C., Kraus, K. C., Struve, C. 2003. Institutionelle Grundlagen der Agrarprotektion: Eine polit-ökonomische Analyse der Agrarpolitik in den Mittle und Osteuropäische Ländern. Journal of Agricultural Economics, Dfv Madiengruppe, Frankfurt. 2003, No. 52, p. 6. ISSN 2191-4028.

[12] Joslin. T. E. International trade policy: the WTO Agenda for agriculture, Centre for Applied Economics and Policy Studies, Agricultural policy discussion paper No 14, Massé University. 1998, [Online] Available: http://agricola.nal.usda.gov/egi-bin/pwebrecon.egi.search_Arg=CAT108768 [Accessed: 14.4.2014].

[13] Keyzer, M. The PSE once more, Vrije-Universiteit Amsterodam. 2002. [Online] Available: http://www.sow.vu.nl./pdf.PSE_once more.pdf. [Accessed: 8.9.2013].

[14] Legg, W. Agricultural Subsidies: Measurement and Use in Policy Evaluation, The Agricultural Economics Society, Journal of Agricultural Economics, 2003, vol. 54, No. 2. [Online] Available: http://onlinelibrary,wiley.conm/journal/10.1111(ISSN)1477-9552 [Accessed: 8.10.2013].

[15] OECD. Monitoring and evaluation: Reference Tables, STATExtracts-Complete databases, 2013. [Online] Available: http://www.oecd-ilibrary.org/, 2013. [Accessed: 10.5.2014].

[16] Wilhelm, V. Daňové úlevy jako součást podpor pro zemědělství, in INPROFORUM Ekonomická krize - výzva pro regiony, České Budějovice. 2009, p. 404-409. ISBN 978-80-7394-173-4.

[17] Tangermann, S. Is the Concept of the PSE in Need of Revision? OECD Food, Agriculture and Fisheries Working Papers No. 1, OECD, Paris, 2005. [Online] Available: http://www.tcd.ie/ economics/staff/amtthews [Accessed: 28.1.2014].

[18] Tangermann, S. Fading support: he truth blind the numbers, OECD Observer, Paris. 2004, No. 243. [Online] Available: http://www. Oecdobserver.org/fading_support [Accessed: 28.1.2014].

[19] Tangermann, S. Response to the article on „How useful is the PSE in determining agricultural support? Food Policy, economics planning and policy of food and agriculture, Elsevier, Amsterdam. 2006, vol. 31. ISBN 0306-9192.

[20] Trdlicová, K. 2010. Zemědělská politika a podpory v zemědělství v zemích OECD, Bulletin ÚZEI, ÚZEI Prague. 2010, No. 11. p.15 - 23. 